\title{
Cultivation of minor tuber crops in Peru and Bolivia
}

\author{
LEENA PIETILÄ and PAULA JOKELA \\ Department of Biology, University of Turku, \\ SF-20500 Turku, Finland
}

\begin{abstract}
A collection mission of three Andean tuber crops, oca (Oxalis tuberosa, Oxalidaceae), ulluco (Ullucus tuberosus, Basellaceae) and añu (Tropaeolum tuberosum, Tropaeolaceae), was carried out in southern Peru, Bolivia and northern Argentina. This article deals with the observations made during this mission. 55 ulluco fields were visited. In general, the fields are small, $240 \mathrm{~m}^{2}$ on average, and they are mostly situated on mountain slopes. The fields are fertilized with animal dung; chemical fertilizers are quite rare. In the fields, people work with hoes ang ploughs as they did hundreds of years ago. Mechanization of agriculture would prevent full utilization of the mountainous area of the Andes. Ulluco is usually interplanted with other crops, usually, many forms of ulluco in one field. Because of crop rotation description of the fields is partly valid for the cultivation of other crops, too. Due to drastic climatic variation, cultivation of mixed varieties may be the best way to guarantee some yield. When results of the investigations are wished to benefit developing countries, knowledge of social, agricultural and environmental factors is of great value.
\end{abstract}

Index words: Ullucus tuberosus, Oxalis tuberosa, Tropaeolum tuberosum, cultivation, tubers, Andean zone

\section{Introduction}

Three endemic Andean tuber crops, ulluco (Ullucus tuberosus-Basellaceae), oca (Oxalis tuberosa-Oxalidaceae) and añu (Tropaeolum tuberosum-Tropaeolaceae) have been investigated at the University of Turku since 1983. The objective of the study is to produce basic knowledge that is needed to breed ulluco, oca and añu, with special reference to the variation pattern of these crops, their reactions to day-length and the problems related to seed formation of ulluco (Rousi et al. 1986, $1988 \mathrm{a}, 1988$ b). Viruses of ulluco and production of disease-free material by tissue culture technology are under investigation at the University of Helsinki.

A mission for collection of the above tuber crops was carried out in southern Peru, Bolivia and northern Argentina during MarchMay in 1987 (Jokela and PIETILÄ 1988). This article deals with observations made during the mission. 


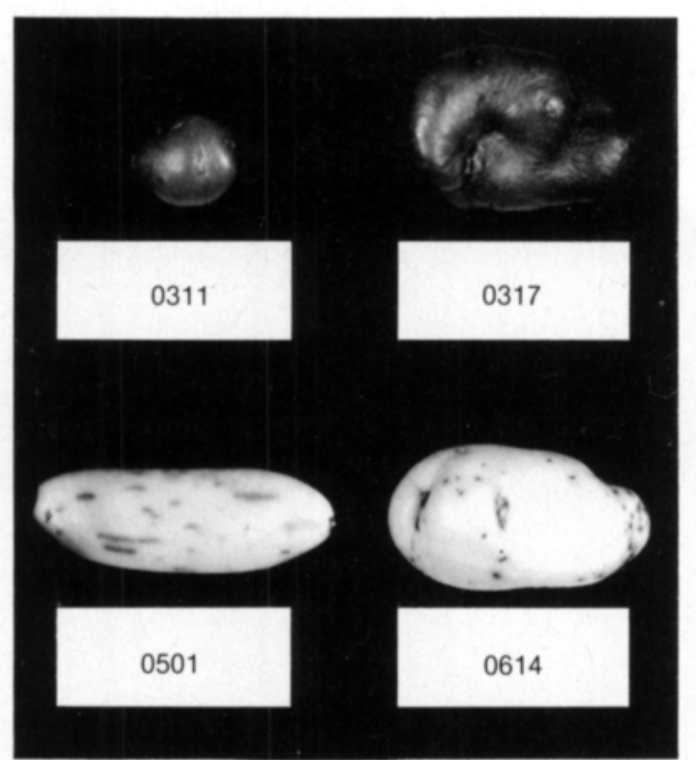

Ulluco

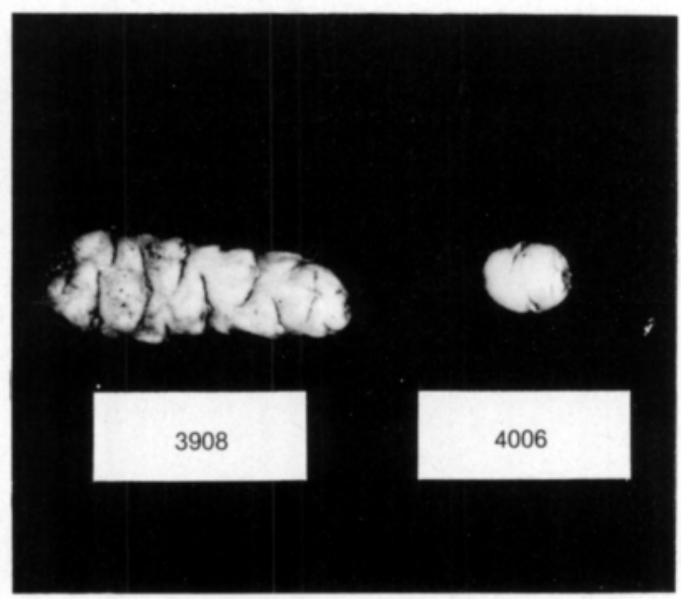

Oca

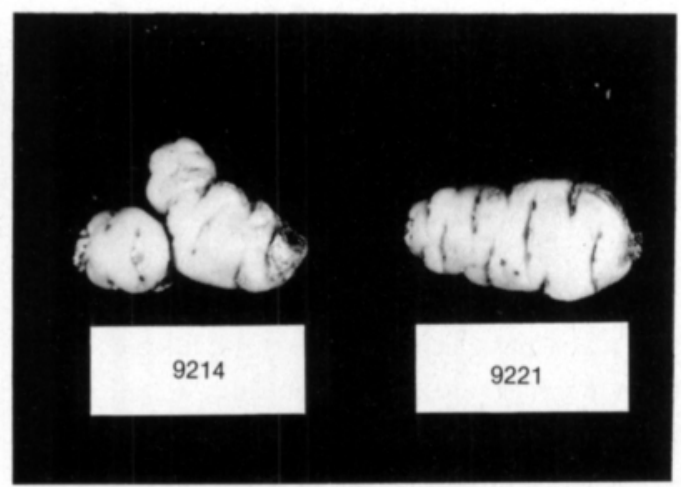

Añu

Fig. 1. Tubers of ulluco, oca, and anu.

\section{Characteristics of ulluco, oca and añu}

Ulluco, oca and añu are viewed as a previously underestimated group of minor edible tuber crops. They are receiving increasing interest in agricultural research. They are cultivated at the same altitude as potato, 2 5004000 metres above sea level, from Colombia to the northern parts of Argentina. Occasionally, oca is cultivated in Mexico and New Zealand, too. Their tubers are of the same size or slightly smaller than those of potato. Tubers of ulluco are white, yellow, orange, red, purple or green, sometimes spotted; those of oca and añu may be white, yellow, red, purple, violet or variegated, with great diversity also in other characteristics.

Ulluco, oca and añu are consumed like potato; their tubers are prepared in a number of ways. The tubers are prepared fresh, or they can be freeze-dried, after which they may be stored for years. They are all important ingredients of soups. Ulluco, which has a slight taste of earth, is prepared in a variety of regional dishes, for instance, with dried meat of alpaca or llama. Tubers of oca contain oxalic acid that gives them the characteristic bitter taste. Possibilities to produce flour, starch and alcohol of oca have been investigated (CORTES 1981). Añu has a very strong taste. It is also a possible source of flour (CORTES et al. 1982). Its tubers have a medicinal and antireproductive value. In the empire of Inca, for instance, the soldiers were given añu as antiaphrodisiac, to make them fight better (JoHNS et al. 1982).

A high percentage of the dry matter content of the tubers is starch. The protein content of ulluco varies from 10.8 to $15.7 \%$, that of oca from 3.0 to $8.4 \%$, and añu from 6.9 to $15.7 \%$ of the dry matter content. The moisture content is $78-92 \%$ of fresh weight (KING 1987).

According to TAPIA (1986), ulluco produces a yield of 3-15 tons per hectare, but it may be as much as 40 tons per hectare if the fields are heavily fertilized (HERQUINIO et al. 1986). Oca and añu yield $4-30$ tons per 
hectare (TAPIA 1986), in optimum conditions up to 45 tons per hectare (HERQuinio et al. 1986). Yields of ulluco and potato, which is the most important tuber crop in the Andean highland, are of the same size in some regions. According to SALIS (1986), in the Valley of Taray, Cusco, the potato yield averages 9.5 tons per hectare and that of ulluco 9.65 tons per hectare. Ulluco is available everywhere in Peruvian and Bolivian markets, even in places where it is not cultivated. Oca is not particularly common, and añu is a rarity in the markets.

Previously ulluco, oca and añu were basic nutrients like potato, maize and some seed crops. Nowadays, with new customs and crops increasingly being imported from other parts of the world, cultivation of ancient crop plants and/or their varieties has declined (KING 1987). Nevertheless, ulluco, oca and añu cannot be substituted. They are an important part of the diet of the Andean people (De Dios Cutipa et al. n.d.) and an indistinguishable part of traditional rotation of crop plants (De Dios Cutipa et al. n.d., CAceda and Rossel 1985). Freeze-dried tubers of potato, ulluco, oca and añu, called chuño, balance the most extreme variety of yields because they can be stored for years (KING 1987). Andean people believe that these tuber crops are more reliable in poor years than imported crops (GARAY 1987). Cultivation of ulluco is labour-saving because it needs only half the labour compared to potato (SALAS 1986). Ulluco, oca and añu are resistant to frost and drought and produce well in poor soils (RE-

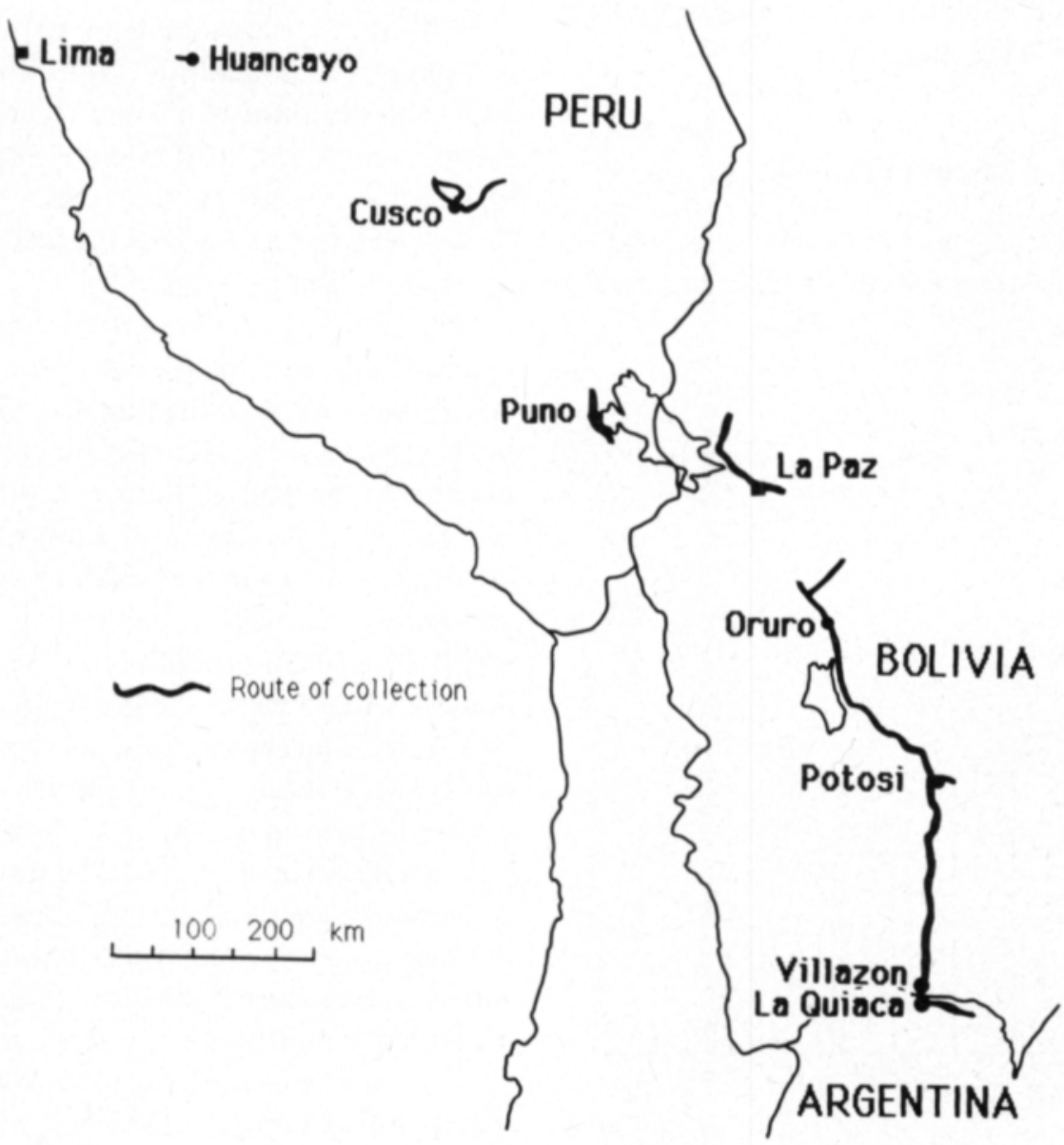

Fig. 2. Routes of the collection mission. 
VILLA 1983). They are potential reserves for many parts of the world, including other mountainous regions of the world (KING 1987).

During the last few years, the value of endemic Andean crop plants has been recognized and much effort is being put to preserve them as part of the Andean agriculture. In Peru, projects to promote investigation, cultivation and utilization of ancient crop plants are being financed by the Government and co-operative organizations.

\section{Methods}

During the collection mission 55 ulluco fields in the area ranging from southern Peru to northern Argentina were visited. The route is shown in Fig. 2. Peasants were interviewed on the cultivation of ulluco, and some field properties were investigated.

\section{Results and discussion}

The ulluco fields visited were classified according to their size (Fig. 3). They are usually

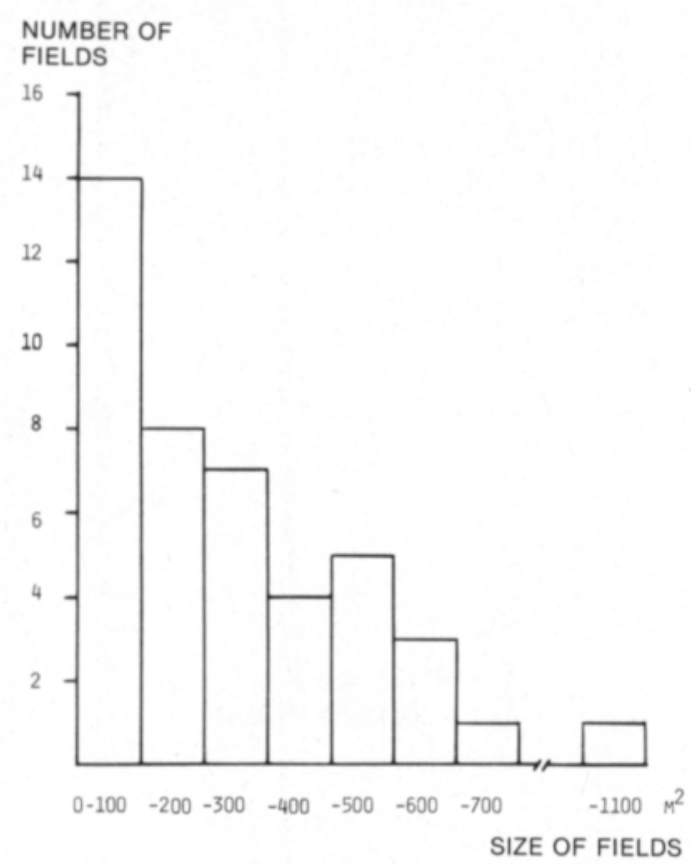

Fig. 3. Size distribution of investigated ulluco fields. small, average size $240 \mathrm{~m}^{2}$. According to DE Dios Cutipa et al. (n.d.), in the Province of Puno, Peru, the arable land per family averages 1.59 hectares, in some areas only 200$500 \mathrm{~m}^{2}$. Generally the cultivation area consists of five or six fields.

$65 \%$ of the fields were on mountains, with a slope of up to $45^{\circ}$. According to CACEDA and Rossel (1985), 95-98\% of the fields in Puno are on mountainslopes.

In ulluco fields, like in any other field, the peasants work with hoes (e.g. chaquitaclla) and ploughs drawn by men or animals as was done hundreds of years ago. None of the farmers interviewed had a tractor or any other machines to work with. In the flat Altiplano there were some tractors in wealthy villages. According to SEPPÄNEN (1986) mechanization of agriculture would prevent full utilization of the Andean highland.

$85 \%$ of the fields were manured with animal dung and, in addition, $29 \%$ were fertilized with chemicals. In Puno, according to CACEdA and Rossel (1985), no chemical fertilization is applied to ulluco, oca and añu fields, and less than $10 \%$ of the fields are fertilized with dung.

The differences between the present investigation and that of CACEDA and ROSSEL (1985) may be due to the fact that the ulluco fields visited were widely distributed, the area ranging from southern Peru to northern Argentina, where the agricultural practice, number of domestic animals, wealth of the people and fertility of the soil vary greatly. CACEDA and Rossel (1985) carried out their investigation in Puno, in one of the Provinces of Peru.

A field usually carries several crops. Ulluco was grown alone in $25 \%$ of the fields visited, it was the principal crop in $20 \%$ and equal or secondary crop in $55 \%$ of the fields. Most commonly it is interplanted with oca, in $52 \%$ of the fields, but we found also ulluco growing with añu, oats, barley and beans. Each species is planted in one or several separate strips.

Crop rotation is common in the whole area visited. All the farmers interviewed utilized the method. Potato is grown in the first year, in 
the second year ulluco, oca and añu or beans, and in the third year cereals, like oats and barley, are grown. Thereafter the field lies fallow for several years (KoHLer 1986). So, the characteristics of ulluco fields are valid for potato and cereal fields, too. But one must take into consideration that ulluco is usually cultivated in poor land and potato and cereals also in lower altitudes and in better fertilized fields.

In a field there were maximally six forms of ulluco classified according to tuber colour and shape. The numbers of tuber forms per field and farmers' stock are shown in Fig. 4. Apparently we did not find all tuber forms in one field, because their numbers in stocks and in fields were significantly different $\left(\mathrm{X}^{2}=\right.$ 11,$10 ; \mathrm{P}=0,1$; d.f. $=2$ ). Potato, for instance, is grown mixed (JACKSON et al. 1980).

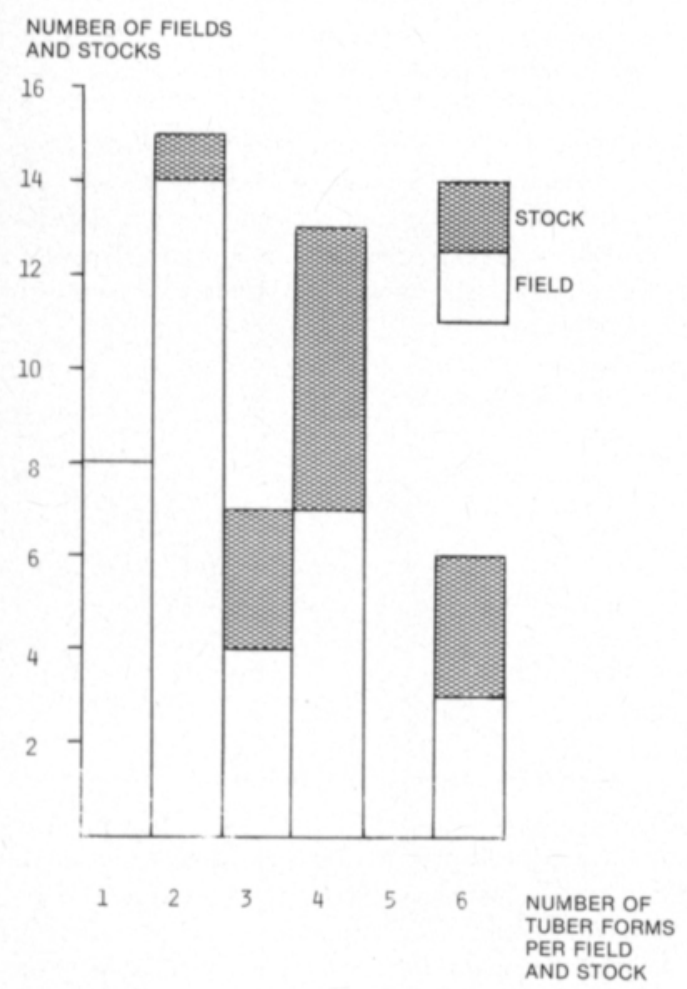

Fig. 4. Numbers of ulluco forms per field and stock in Peru, Bolivia and northern Argentina. Ulluco forms are classified according to tuber color and shape.
So, the degree of variation in ulluco field is probably underestimated.

Each ulluco form is usually consumed in a different way. Red tubers are grown in some regions because of their medicinal value, e.g. for gastrointestinal diseases of domestic animals. Plants with red tubers are also thought to be more frost-resistant than others. Yellow tubers are the most popular ones for food, and they are grown for sale. In the markets, yellow tubers of ulluco were generally by far the most common. However, some farmers claim that there is no difference in the consumption of different tuber forms.

\section{Conclusions}

In the high Andes the climate varies in different years drastically. It is probably impossible to produce a variety that could give a good yield every year. According to MARTIN and AdAms (1987), heterogeneous crop populations may be better buffered against climatic and biological factors. So, the traditional way of cultivating several varieties by one farmer is perhaps the best way to guarantee the yield.

Investigations made in developed countries with the intention to benefit developing countries, should consider tradition and the possibilities to utilize the results. In this respect knowledge of social, agricultural and environmental factors may be of great value. In the breeding of ulluco, oca, and añ, for instance, attention should be paid to the fact that most peasants who cultivate these plants cannot afford machines. Another point is that it may be nearly impossible to work with them: the fields are small and they are situated on steep mountain slopes with rough erosionsensitive soil. So there is no use improving ulluco, oca and añu varieties for cultivation by machines in Peruvian or Bolivian fields.

Acknowledgements. The authors wish to thank Prof. Arne Rousi for his valuable comments and suggestions on the mission and the manuscript and the Academy of Finland for financial support. 


\section{References}

Caceda, F. and Rossel, J. 1985. Entomología de los cultivos andinos. Estudio en comunidades campesinas. 104 pp. Puno, Peru.

Cortes, H.B. 1981. Avances de investigacion en tres tubérculos andinos. In: "Curso sobre manejo de la producción agraria en laderas". Huaraz, serie ponencias, resultados, recomendaciones de eventos, tecnicos 235 . IICA, Bogotá, Colombia (ref. King 1987).

Cortes, H., Deza, F.H. and Jiménez, S. 1982. Obtención y evaluación de harina de maswa (Tropaeolum tuberosum). In: III Congreso Internacional de Cultivos Andinos. pp. 331-334. La Paz, Bolivia.

De Dios Cutipa, J., Salas, B., Vilcatoma, L., Mayta, J. and Снамвi, E. (n.d.). Proyecto: Cultivos andinos. Informe final. $199 \mathrm{pp}$. Convenio de cooperación interuniversitaria Peru-Holanda. Puno, Peru.

Garay, O. 1987. El cultivo de los tubérculos andinos. Minka 21: 7-16.

Herquinio, F., Toribio, L., Román, F. and Muñoz, T.A.A. 1986. Informe de investigación 1984-85, 1985 - 86. 16 pp. Universidad Nacional del Centro del Peru. El Mantaro, Peru.

Jackson, M.T., Hawkes, J.G. and Rowe, P.R. 1980. An ethnobotanical field study of primitive potato varieties in Peru. Euphytica 29: 107-113.

Johns, T., Kitts, W.D., Newsome, F. and Towers, G.H.N. 1982. Anti-reproductive and other medicinal effects of Tropaeolum tuberosum. J. Ethnopharmacology 5: 149-161.

Jokela, P. and Pietila, L. 1988. Collecting minor tuber crops in the Andes. Pl. Gen. Resources Newsl. (in press.)

KING, S.R. 1987. Four endemic Andean tuber crops:
Promising food resources for agricultural diversification. Mount. Res. Dev. 7: 43-52.

Kohler, A. 1986. Sistemas del uso de suelos en laderas de Cajamarca, Peru. In: Anales V Congreso Internacional de Sistemas Agropecuarios Andinos. Puno, Peru. pp. 89-99.

Martin, G.B. and Adams, M.W. 1987. Landraces of Phaseolum vulgaris (Fabaceae) in northern Malawi. I. Regional variation. Economic Bot. 41: 190-203.

Revilla, J.L. 1983. Conservación de productos agrícolas en el campo. Minka 10: 20-24.

Rousi, A., Salo, J., Kalliola, R., Jokela, P., Pietila, L. and YLI-ReKolA, M. 1986 Variation pattern in ulluco (Ullucus tuberosus-Basellaceae), a supposedly asexual Andean tuber crop. Acta Hort. 182: 145-152.

Rousı, A., Yli-Rekola, M., Jokela, P., Kalliola, R., PietilA, L. and SAlo, J. 1988 a. The fruit of Ullucus (Basellaceae), an old enigma. Taxon 37: 000-000.

Rousi, A., Jokela, P., Kallola, R., Pietilà, L., Salo, J. and YLI-REKOLA, M. 1988 b. Morphological variation among clones of ulluco (Ullucus tuberosus, Basellaceae) collected in Southern Peru. Economic Bot. (approved).

SAlas, A. 1986. Perspectivas y condiciones de promoción de los cultivos andinos autoctonos. In: Anales V Congreso Internacional de Sistemas Agropecuarios Andinos. Puno, Peru. pp. 425-432.

SeppÃnen, M. 1986. Mikă luonnoista luonnollisin. Kehitysmaantieteen yhdistyksen toimitteita: 16. $148 \mathrm{pp}$.

TAPIA, M.E. 1986: Los cultivos andinos subexplotados de valor nutricional en el Peru. $18 \mathrm{pp}$. Unpublished lecture in Conference in Santiago, Chile, October 7-10 in 1986.

Ms received December 21, 1987

\section{SELOSTUS}

\section{Huonosti tunnettujen mukulakasvien viljely Perussa ja Boliviassa}

\section{Leena Pietilä ja Paula Jokela \\ Biologian laitos, Turun yliopisto, 20500 Turku}

Kevăăllă 1987 tehtiin kolmen Andien endeemisen mukulakasvilajin, ullucon (Ullucus tuberosus-Basellaceae), ocan (Oxalis tuberosa-Oxalidaceae) ja añun (Tropaeolum tuberosum-Tropaeolaceae), keräys- ja tutkimusmatka Etelä-Peruun, Boliviaan ja Pohjois-Argentiinaan. Artikkeli perustuu tehtyihin havaintoihin.

Matkan aikana käytiin 55 ulluco-pellolla. Viljelmăt ovat yleensă pieniă, keskimaaărin $240 \mathrm{~m}^{2}$ ja sijaitsevat jyrkillă vuorenrinteillä. Peltoja lannoitetaan useimmiten eläinten lannalla, eikä kaupasta hankittuja lannoitteita juuri käytetă. Pelloilla tyőskennelläăn edelleen perinteisin me- netelmin. Yhdellă pellolla viljellăăn yleensă useaa kasvilajia rinnakkain ja samastakin lajista useaa morfologisin tuntomerkein erotettavaa muotoa. Viljelykasvilajin muuntelevuus auttaa torjumaan tauteja ja tuhoelăimiă sekă lieventaaă epăvakaan ilmaston vaikutuksia. Perinteinen tapa viljellă useita eri lajikkeita on mahdollisesti paras tapa taata sato. Kehitysmaissa sovellettavaksi aiotut tutkimukset vaativat onnistuakseen alueen olojen tuntemusta. Sosiaaliset olot, perinne sekä ilmastolliset ja muut ympäristötekijät vaikuttavat tutkimustulosten hyödynnettävyyteen. 